John Carroll University

Carroll Collected

2017

\title{
Audit fee discounting in the post-SOX environment
}

\author{
Albert Nagy \\ John Carroll University, alnagy@jcu.edu \\ Benjamin W. Hoffman \\ Kent State University
}

Follow this and additional works at: https://collected.jcu.edu/fac_bib_2017

Part of the Accounting Commons

\section{Recommended Citation}

Nagy, Albert and Hoffman, Benjamin W., "Audit fee discounting in the post-SOX environment" (2017). 2017 Faculty Bibliography. 35. https://collected.jcu.edu/fac_bib_2017/35

This Article is brought to you for free and open access by the Faculty Bibliographies Community Homepage at Carroll Collected. It has been accepted for inclusion in 2017 Faculty Bibliography by an authorized administrator of Carroll Collected. For more information, please contact connell@jcu.edu. 


\section{e emeraldinsight}

\section{Managerial Auditing Journal}

Audit fee discounting in the post-SOX environment

Benjamin W. Hoffman, Albert L. Nagy,

\section{Article information:}

To cite this document:

Benjamin W. Hoffman, Albert L. Nagy, (2017) "Audit fee discounting in the post-SOX environment", Managerial Auditing Journal, Vol. 32 Issue: 7, pp.715-730, https://doi.org/10.1108/MAJ-03-2016-1335 Permanent link to this document:

https://doi.org/10.1108/MAJ-03-2016-1335

Downloaded on: 02 October 2017, At: 11:14 (PT)

References: this document contains references to 34 other documents.

To copy this document: permissions@emeraldinsight.com

The fulltext of this document has been downloaded 41 times since 2017*

\section{Users who downloaded this article also downloaded:}

(2017),"Does family ownership reduce corporate tax avoidance? The moderating effect of audit quality", Managerial Auditing Journal, Vol. 32 Iss 7 pp. 731-744 <a href="https://doi.org/10.1108/ MAJ-02-2017-1530">https://doi.org/10.1108/MAJ-02-2017-1530</a>

(2017),"What can auditors tell us about accounting manipulations?", Managerial Auditing Journal, Vol. 32 Iss 8 pp. 788-809 <a href="https://doi.org/10.1108/MAJ-03-2017-1534">https://doi.org/10.1108/ MAJ-03-2017-1534</a>

Access to this document was granted through an Emerald subscription provided by emeraldsrm: 405700 []

\section{For Authors}

If you would like to write for this, or any other Emerald publication, then please use our Emerald for Authors service information about how to choose which publication to write for and submission guidelines are available for all. Please visit www. emeraldinsight.com/ authors for more information.

\section{About Emerald www.emeraldinsight.com}

Emerald is a global publisher linking research and practice to the benefit of society. The company manages a portfolio of more than 290 journals and over 2,350 books and book series volumes, as well as providing an extensive range of online products and additional customer resources and services.

Emerald is both COUNTER 4 and TRANSFER compliant. The organization is a partner of the Committee on Publication Ethics (COPE) and also works with Portico and the LOCKSS initiative for digital archive preservation.

*Related content and download information correct at time of download. 


\title{
Audit fee discounting in the post-SOX environment
}

\author{
Benjamin W. Hoffman \\ Department of Accounting, Kent State University, Kent, Ohio, USA, and \\ Albert L. Nagy \\ Department of Accountancy, John Carroll University, University Heights, \\ Ohio, USA
}

\begin{abstract}
Purpose - This paper aims to investigate whether the expected implementation of Section 404(b) of the Sarbanes-Oxley Act (SOX 404(b)) (the integrated audit requirement) caused auditors to discount their audit fees for non-accelerated filers in anticipation of expected increased future economic rents (DeAngelo, 1981) from those clients.

Design/methodology/approach - This paper predicts that auditors charged their non-accelerated filer clients lower audit fees during the years 2005-2007 (in anticipation of increased expected future economic rents from the implementation of the SOX 404(b) requirement) compared with the years 20102012 (when it had been determined that non-accelerated filers were permanently exempt from complying with SOX 404(b)). The authors use ordinary least squares regression analysis to examine whether audit fees increased significantly for non-accelerated filers after the permanent exemption announcement.
\end{abstract}

Findings - The results show a significant positive association between the exemption announcement and audit fees, supporting the theory that auditors discounted their audit fees for non-accelerated filers in the preexemption announcement period. This finding is robust when sensitivity tests are used.

Practical implications - The findings of audit fee discounting literature related to the post-SOX period are mixed. This study adds to this stream of literature by supporting the notion that audit fee discounting is being practiced post-SOX and is a potential unintended consequence of SOX 404 and the exemption. Thus, investors will be interested in the results of this paper when making their investment decisions with regard to non-accelerated filers.

Social implications - The results of this paper show that, even in the post-SOX environment, auditors will employ the use of audit fee discounting if a change in regulation incentivizes it. This commentary on the present state of the audit pricing market should be of interest to audit pricing policymakers.

Originality/value - This paper is one of the first to study audit fee discounting outside the realm of initial audit engagements.

Keywords Audit fees, Audit pricing, Internal control, SOX 404, Audit fee discounting

Paper type Research paper

\section{Introduction}

The practice of audit fee discounting has been a concern of regulators for the past four decades (AICPA, 1978; PCAOB, 2011). There are two primary concerns regarding auditors engaging in this practice. First, regulators are concerned that audit fee discounting impairs an auditor's independence. If auditors are discounting their fees to obtain or retain a client, they will be motivated to keep that client long enough to recoup the losses incurred from the discounted fees. This motivation could impair the auditors' independence, as they may be more willing to give in to management pressures if the auditors are concerned about losing the client (PCAOB, 2011). Second, regulators are 
concerned that audit fee discounting will decrease audit quality. When charging lower audit fees than they should, auditors may be motivated to "cut corners" during their completion of the audit to incur smaller losses. Several State Boards of Accountancy have shown evidence of this occurring (Hansen, 2010).

Prior literature has studied this phenomenon to:

- determine whether audit fee discounting is occurring in practice; and

- allay or confirm these regulator concerns.

DeAngelo (1981) theorized that auditors engage in this practice to earn future economic rents. Starting with Simon and Francis (1988), several studies have found (empirically) the existence of initial audit fee discounting (Kanodia and Mukherji, 1994; Stanley and DeZoort, 2007). This prior research focuses on whether audit firms engage in initial audit fee discounting, i.e. lowballing, to obtain clients with the expectation of recouping the discounts from future engagements. A related question that has not been addressed by the research is whether audit firms engage in audit fee discounting of existing clients whose audit fees are expected to increase significantly for future engagements. Our study addresses this question by examining audit fee discounting in a unique setting: the planned implementation, delay and ultimate exemption of the Sarbanes-Oxley Act: Section 404(b) (SOX 404(b)) integrated audit requirement for nonaccelerated filers ("the exemption"). Analyzing audit fee pricing in this setting allows us to consider the possibility of the practice of audit fee discounting outside the realm of initial audit pricing. In other words, we are able to ask the question: Does an expected future regulatory change (one that will increase future economic rents) motivate auditors to discount their present audit fees?

We select a sample of non-accelerated filers during the pre-(2005-2007) and post-(20102012) SOX 404(b) exemption periods to estimate an ordinary least squares (OLS) regression that measures the exemption effect on audit fees. The results show that audit fees for nonaccelerated filers are significantly lower during the pre-SOX 404(b) exemption period than during the post-SOX 404(b) exemption period.

Our study contributes to accounting literature in several ways. First and foremost: to our knowledge, this is one of the few studies that addresses audit fee discounting outside of the realm of initial audit fee discounting. Our unique setting of the implementation of SOX 404(b) and the subsequent exemption for non-accelerated filers allows us to do so. Thus, we identify audit fee discounting across both new and continuing non-accelerated audit clients. This finding should be of interest to regulators, investors, audit committee members and academics that are concerned about the potential consequences of audit fee discounting. Also, the findings of audit fee discounting literature related to the post-SOX period are mixed: some studies find evidence of a decrease or elimination of audit fee discounting post-SOX (Ghosh and Pawlewicz, 2009; Huang et al., 2009), while others find the continued use of audit fee discounting post-SOX (Ghosh and Lustgarten, 2006; Sankaraguruswamy and Whisenant, 2009; Sankaraguruswamy et al., 2012; Desir et al., 2014; Ettredge et al., 2014; Krishnan and Zhang, 2014). Our study adds to this stream of literature by supporting the notion that audit fee discounting is being practiced post-SOX and is a potential unintended consequence of SOX 404 and the exemption. Finally, we contribute to the audit pricing literature by showing that, even in the post-SOX environment, auditors will employ the use of audit fee discounting if a change in regulation allows the expected future economic rents to outweigh the initial costs of doing so. This commentary of the present state of the audit pricing market should be of interest to regulators, investors, audit committee members and academics as the market continues to evolve. 
The remainder of this paper is organized as follows: the next section discusses prior research related to this topic as well as the motivation and logic supporting our hypothesis. The following section describes the sample, research method and variable definitions. Next, we discuss and analyze the results of our models. Finally, we summarize the study and identify any limitations.

\section{Background, prior research and hypothesis development \\ Background and prior research}

Audit fee discounting. Several prior studies have theorized about and examined data related to the concept of the discounting of audit pricing. DeAngelo (1981) was the first research paper to address this topic: she theorized that auditors discount initial audit engagements (termed "low-balling") due to the anticipation of increased future economic rents. Incumbent auditors were expected to earn higher profits in subsequent audits due to start-up costs to the auditor in the first year as well as the hesitation of clients to switch auditors after that first year due to significant switching costs. Simon and Francis (1988) studied this empirically, finding a significant audit fee reduction for initial audit engagements, with fees increasing to normal levels by the fourth year of the audit. Several subsequent studies also found evidence of initial audit fee discounting in various settings and periods (Ettredge and Greenberg, 1990; Craswell and Francis, 1999; Walker and Casterella, 2000; Ghosh and Lustgarten, 2006; Sankaraguruswamy and Whisenant, 2009; Ghosh and Pawlewicz, 2009; Sankaraguruswamy et al., 2012; Desir et al., 2014).

The focus of this stream of prior literature is on initial audit fee discounting; our setting gives us the ability to examine audit fee discounting for both new and continuing audit clients in an environment where fees are expected to significantly increase for a group of clients due to a change in regulation. This practice of audit fee discounting naturally raises concerns about possible negative effects. There are two primary concerns about potential adverse effects of initial audit fee discounting. The first concern is in relation to compromised auditor independence. Some regulators worried that the performance of audit services below cost with the intention of recovering those losses in future years would impair the auditor's independence due to their implicit commitment to the client due to this long-term plan (AICPA, 1978). Simon and Francis (1988) found support for this in their study when considering the psychological theory of sunk costs. They found that inconsistent with the sunk cost theory, taking an initial loss does significantly affect subsequent decision-making. Thus, in the context of auditing, audit fee discounting commits the auditor to the client until that initial loss is recovered. More recently, there has been empirical research to support the notion that initial audit fee discounting impairs the auditor's independence (Stanley and DeZoort, 2007). Specifically, Stanley and DeZoort (2007) find a significant negative relation between audit fees and restatements and conclude that this is consistent with concerns that lowball audit pricing strategies jeopardize auditor independence. Another potential adverse by-product of initial audit fee discounting is increased susceptibility to management pressures if the auditor is concerned about maintaining a long-term relationship with management to recover initial losses.

The second primary concern about initial audit fee discounting is deterioration of audit quality for those firms that participate in the practice of this discounting. This concern was initially addressed in prior theoretical research (Kanodia and Mukherji, 1994), stating that initial audit fee discounting erodes audit quality. More recently, regulators have stated this concern consistently. For example, the PCAOB suggested the following in a concept release:

Or, if as some have suggested auditors bid on new engagements with the assumption that they will lose money in the first years of an engagement but recoup that loss over a long period of time, 
the problem may be unrealistic pricing, with a resulting effect on audit effort or resources at the beginning of an auditor-client relationship (PCAOB, 2011).

In addition, the National Association of State Boards of Accountancy (NASBA) issued a discussion paper on this topic, stating that State Boards of Accountancy have recently identified instances of unacceptable audit practices related to underpriced audits (Hansen, 2010). More specifically, audit firms in these situations are failing to investigate material misstatements in financial statements.

These perceptions of audit fee discounting provide motivation to identify specific settings in which audit fee discounting is encouraged by that setting. Specifically, audit fee discounting may potentially occur in situations that the audit firm expects more work in the future, and in turn, more revenue from the client. For example, audit fee discounting may occur for clients whom the auditor anticipates increased rents from expected merger and acquisition activity, global growth and secondary offerings. The implementation of SOX 404(b) internal control audits and the subsequent exemption of non-accelerated filers from having to complete those audits provides us with just such a unique setting.

Sarbanes-Oxley Act 404(b) and the exemption. SOX 404(b) created the requirement that public companies be subject to an integrated audit, which includes two audit opinions: one opinion on whether the financial statements are free of material misstatement, and one opinion on whether the company's internal controls over financial reporting are free of material weaknesses. This requirement caused much controversy in the business community primarily due to significant compliance costs, particularly for smaller public companies (Krishnan et al., 2008). Due to this burden on smaller public companies, the deadline for non-accelerated filers to comply with SOX 404(b) was continually delayed[1]. Ultimately, these companies are indefinitely exempt from having to comply with this requirement. This was established by the Dodd-Frank Consumer Protection Act in July 2010 (H.R. 4173, 2010).

Despite the continued delays of SOX 404(b) compliance for non-accelerated filers, there was little if any anticipation of the exemption by auditors and their clients. In October 2009, the first evidence of a possible permanent exemption was mentioned in the business press: on October 8, 2009, the Small Business SOX Compliance Relief Act was introduced to Congress by Representative Scott Garrett (H.R. 3775, 2009), which proposed the permanent exemption. Based on a comprehensive search, there was no mention of the possibility of a permanent exemption prior to this date[2]. This fact allows us to consider the possibility that auditors offered discounted audit pricing to their non-accelerated clients in anticipation of the significant additional fees they would earn when SOX 404(b) compliance was required. Auditors could accurately anticipate the future additional SOX 404(b) fees due to the work already being performed for their accelerated-filer clients. Prior research documents significant audit fee increases (i.e. from 86 to 359 per cent) for accelerated filers from the preto post-SOX 404(b) requirement periods (Raghunandan and Rama, 2006; Krishnan et al., 2008).

\section{Hypothesis development}

Prior audit fee discounting research examines initial audit fee discounting by isolating fees in the first year of an audit and comparing those fees to subsequent years' fees through regression analysis. As described above, we examine audit fee discounting for existing clients under the unique environment created by SOX 404(b) and its subsequent exemption for nonaccelerated filers. There is a three-year period (2005-2007) where auditors are anticipating future economic rents to occur for non-accelerated filers when integrated audits become required for those companies. Based on the theory proposed by DeAngelo (1981), 
there is clear incentive for auditors to entice or retain non-accelerated clients with lower fees to earn substantial future economic rents with the performance of the integrated audit in the future.

We expand DeAngelo's (1981) theory to beyond that of the initial audit engagement by suggesting that subsequent audit fee negotiations involve auditors weighing engagement risks and costs versus the expected future quasi rents. Consistent with DeAngelo's (1981) theory, we propose that the expected future quasi rents and current period audit fees are inversely related, ceteris paribus. The regulatory shock of the permanent SOX 404(b) exemption caused a significant reduction in the expected future quasi rents of nonaccelerated filer clients and, in turn, increased the current audit fees of these clients. This leads to the following hypothesis:

H1. Non-accelerated filers had higher audit fees after the SOX 404(b) permanent exemption than before the exemption.

\section{Research design}

Sample

Ghosh and Lustgarten (2006) find that audit fee discounting and competition is greater among small audit firms than it is among large audit firms. They show that about 9 per cent of the largest audit firms' clients are new clients as compared to that of about 34 per cent for smaller audit firms' clients. The non-accelerated filers' market primarily consists of smaller audit firms and provides a ripe setting to examine the potential practice of audit fee discounting.

The sample for this study consists of non-accelerated filers covering a pre- and postexemption period, for the years 2005 to 2007 and 2010 to 2012, respectively. This study attempts to capture auditor reactions to the lost future economic rents due to the exemption. The pre- and post-exemption period cut-off should be the time when auditors anticipated the exemption and in turn the lost future rents. To select the appropriate cutoff date, we researched the dates of the key events leading up to the implementation of the exemption by the Dodd-Frank Consumer Protection Act in July 2010. Initially, the effective date of SOX 404(b) compliance for nonaccelerated filers was fiscal year-ends beginning with December 15, 2007. However, this deadline was extended three times: to December 15, 2008, December 15, 2009, and finally June 15, 2010; this final extension was announced on October 2, 2009 (Aguilar, 2009a). Also in October 2009, the first evidence of a possible permanent exemption was mentioned in the business press: on October 8, 2009, the Small Business SOX Compliance Relief Act was introduced to Congress by Representative Scott Garrett (H.R. 3775, 2009). This bill proposed the permanent exemption of non-accelerated filers from compliance with SOX 404(b). This bill became part of the Wall Street Reform and Consumer Protection Act, which was passed by Congress on December 11, 2009 (Aguilar, 2009b). Ultimately, this bill became the Dodd-Frank Consumer Protection Act, which became effective in July 2010.

Based on this timeline, we conclude that by 2008, auditors began considering the possibility of the exemption, and by the end of 2009, they anticipated the exemption as a (most likely) permanent exemption. We separate the pre- and post-exempt periods by eliminating 2008 and 2009, the two-year period when the likelihood of the exemption or the SOX 404(b) requirement for non-accelerated filers was in a state of uncertainty. The pre- and post-exemption sample periods, 2005 to 2007 and 2010 to 2012, respectively, allows for the comparison of audit pricing between periods in which auditors had different expectations regarding future SOX 404(b) audit work. 
We establish the start of the pre-exemption period as 2005 for two reasons. First, prior to 2005, SOX and the PCAOB's related auditing standard (Auditing Standard No. 2 (AS 2)) were in the process of being implemented, and AS 2 became effective for accelerated filers with fiscal year-ends of November 15, 2004 or later (PCAOB, 2004). Thus, auditor expectations regarding these new regulations were uncertain between 2002 and 2004. Second, by 2005, auditor expectations became clear: non-accelerated filers will need to comply with SOX 404(b) imminently. This also allows us to have a consistent length (three years) for the pre- and post-exemption periods.

Our initial sample includes all non-accelerated filer companies for the pre- and postexemption periods (2005-2007 and 2010-2012) that had audit fees per the Audit Analytics data base and the same filer status from the pre- to post-periods. The market capitalization (share price $\times$ common stock outstanding) determined the filing status of the sampled companies. That is, the observations with less than US $\$ 75 \mathrm{~m}$ of market capitalization are classified as nonaccelerated filers for this study[3]. Table I presents a description of the sample. The initial sample included 7,758 firm-year observations. Given the fundamentally different operating characteristics associated with financial institutions, we exclude observations with an SIC Code in the 6000s (1,701 observations). A total of 1,073 observations were omitted because they did not have the sufficient control variables' data from Research Insight. This leaves a final sample of 4,984 firm-year observations, which consists of 2,302 in the pre-exemption period and 2,682 in the post-exemption period.

\section{Models}

We rely on prior audit fee research (Francis et al., 2005; Nagy, 2014) in determining an appropriate OLS regression model to test the SOX 404(b) exemption effect on audit fees (H1). The OLS regression model is specified as follows:

$$
\begin{aligned}
L A F= & \alpha+\beta_{1} E X E M P T+\beta_{2} S I Z E+\beta_{3} S E G+\beta_{4} C A T A+\beta_{5} Q U I C K+\beta_{6} L E V \\
& +\beta_{7} R O A+\beta_{8} G C+\beta_{9} B U S Y+\beta_{10} L O S S+\beta_{11-59} I N D
\end{aligned}
$$

where:

$L A F \quad=$ natural log of audit fees in dollars;

EXEMPT $=1$ if post-SOX 404(b) exemption period (2010-2012), 0 for pre-SOX 404(b) exemption period (2005-2007);

SIZE = natural log of total assets;

$S E G \quad=$ natural log of the number of reported business segments;

$C A T A=$ ratio of current assets to total assets;

QUICK = ratio of current assets (less inventories) to current liabilities;

$L E V \quad=$ ratio of debt to total assets;

Table I.

Sample description
Initial sample ${ }^{\mathrm{a}}$

Financial institution (SIC in 6000s)

Missing control variables data per Research Insight

Final sample

Notes: ${ }^{\text {a }}$ The initial sample includes all non-accelerated filer firm-year observations from the Audit Analytics data base for the years 2005 to 2007 and 2010 to 2012, with audit fees data and did not change filer status from the pre- to post-exemption periods 
$R O A=$ return on assets for the year;

$G C=1$ if audit report is modified for going-concern, 0 otherwise;

$B U S Y \quad=1$ if the fiscal year end is in December, January, February or March, 0 otherwise;

LOSS $\quad=1$ if net income is negative, 0 otherwise; and

IND = dummy variables based on two-digit SIC codes (49 industries).

A significant and positive coefficient on the EXEMPT variable would support $H 1$ and suggest that non-accelerated filers experienced discounted audit fees in the pre-exemption period. The control variables were derived from prior audit fee research and control for cross-sectional differences in factors that affect audit fees such as client size, audit complexity and audit risk (Simunic, 1980; Craswell et al., 1995; Frankel et al., 2002; Ferguson et al., 2003; Francis et al., 2005). Specifically, higher fees are expected (positive coefficients) for larger clients $(S I Z E)$, for those with greater audit complexity, risk and effort (SEG, $C A T A, L E V, L O S S$ and $G C$ ), and for busy season clients (BUSY). Lower audit fees are expected (negative coefficients) for more liquid and profitable clients (QUICK and ROA). Finally, the dummy variables $I N D$ control for any industry fixed effects.

\section{Results}

Main results

Table II presents pre- and post-exemption descriptive statistics for the study's variables of interest. The mean of the $L A F$ variable significantly increases from the pre- to post-exempt periods $(p<0.01)$. This result suggests that non-accelerated filers had higher audit fees after the exemption, and supports $H 1[4]$.

The univariate comparisons further indicate that the sample observations, on average, increased in size (SIZE), number of business segments $(S E G)$ and issuance rates of going concern reports $(\mathrm{GC})$ from the pre- to post-exempt period. The pre- to post-exempt changes for the remaining variables are not significant at any conventional level.

\begin{tabular}{lcccc}
\hline Variable $^{\mathrm{a}}$ & Total $(n=4,984)$ & Pre-exempt $(n=2,302)$ & Post-exempt $(n=2,682)$ & Difference $^{\mathrm{b}}$ (Post-Pre) \\
\hline LAF & $12.076(11.932)$ & $12.007(11.876)$ & $12.135(11.970)$ & $0.128^{* * * *}$ \\
SIZE & $3.372(3.088)$ & $3.283(3.018)$ & $3.448(3.147)$ & $0.165^{* *}$ \\
SEG & $0.206(0.000)$ & $0.150(0.000)$ & $0.254(0.000)$ & $0.104^{* * * *}$ \\
CATA & $2.778(1.443)$ & $2.708(1.505)$ & $2.839(1.399)$ & 0.131 \\
QUICK & $2.229(1.048)$ & $2.149(1.093$ & $2.297(1.012)$ & 0.148 \\
LEV & $1.594(0.232)$ & $1.908(0.210)$ & $1.324(0.247)$ & 0.584 \\
ROA & $-64.483(-1.943)$ & $-60.482(-1.056)$ & $-67.918(-2.708)$ & -7.436 \\
GC & $0.230(0.000)$ & $0.213(0.000)$ & $0.245(0.000)$ & $0.032^{* * * *}$ \\
BUSY & $0.653(1.000)$ & $0.655(1.000)$ & $0.651(1.000)$ & -0.004 \\
LOSS & $0.535(1.000)$ & $0.525(1.000)$ & $0.544(1.000)$ & 0.019
\end{tabular}

Notes: $* *$ and $* * *$ indicate significance at $p<0.05$ and $p<0.01$, respectively (one-tailed tests where relation is predicted); ${ }^{a}$ Variable definitions: LAF = natural log of audit fees in dollars, SIZE = the natural $\log$ of total assets, SEG = natural log of the number of reported business segments, CATA = ratio of current assets to total assets, QUICK = ratio of current assets (less inventories) to current liabilities, LEV = ratio of debt to total assets, ROA = return on assets for the year, $\mathrm{GC}=1$ if audit report is modified for going concern, 0 otherwise, BUSY = 1 if the fiscal year end is December through March, 0 otherwise, LOSS = 1 if net income is negative, 0 otherwise; ${ }^{b}$ tests for differences in the means are based on $t$-statistics ( $z$-statistics) for continuous variables (proportions); Nonparametric tests for differences in location are based on the Wilcoxon rank sum test

Table II.

Descriptive statistics mean (median) 
The correlations among the variables are presented in Table III. The significant and positive correlation between $L A F$ and EXEMPT suggest audit fees were higher in the postexemption period and supports our hypothesis. The general correlations between $L A F$ and the remaining independent variables suggest that larger, more complex, financially healthy companies tend to have higher audit fees. Furthermore, audit fees tend to be higher (lower) for companies audited during the busy season (receiving a going concern opinion). As expected, the control variables that tend to increase with company size (SIZE, SEG) are positively (negatively) correlated with financial health (distress) (ROA, LOSS). The remaining correlations are generally consistent with expectations.

Table IV presents the results of the OLS regression model used to test the exemption effect on audit fees. The model is highly significant $(p<0.01)$ and the adjusted $R^{2}$ is 76.57 per cent. The positive and significant EXEMPT variable suggests that audit fees increased from the pre- to the post-exempt period for non-accelerated filers. The EXEMPT coefficient reflects a 4.7 per cent increase in audit fees from the pre- to post-exempt periods[5]. This result supports $H 1$. The control variables SIZE, SEG, LEV, ROA, GC, BUSY and LOSS are significant and in the predicted direction, and suggest that audit fees increase for larger companies that exhibit higher audit risk, complexity and effort. The remaining control variables are not significant.

\section{Additional analyses}

We perform four additional analyses to test the robustness of the reported result. First, we reestimate the regression model only using companies that retained the same audit firm throughout the study period. Second, as a frame of reference or benchmark, we examine the audit fee changes for accelerated filers from the pre- to post-exemption periods and compare their change to that of non-accelerated filers. Third, the audit fee discounting of initial audit engagements is measured separately in the regression model. Fourth, we consider and control for a possible auditor size effect on the reported result in the regression. Finally, we analyze audit fee levels during a third sample period prior to our pre-exemption period: 2002-2004 and compare audit fees during that period to audit fees in the pre- and post-exemption periods.

For the first additional analysis, the regression model was estimated using only companies that had the same auditor throughout the six-year test period (2005-2007 and 2010-2012). By including only same-auditor companies in the sample, we control for any potential auditor change effects on audit fees. This analysis also mitigates the possibility of any unforeseen unique pre- and post-exemption subsample effects because the same companies are included in each subsample.

Table $\mathrm{V}$ presents the results of the OLS regression model estimated using companies with the same auditor throughout the sample period $(n=1,215)$. The model is highly significant $(\phi<0.01)$ and the adjusted $R^{2}$ is 86.73 per cent. Consistent with the Table III results, the EXEMPT variable is positive and significant, and is evidence that audit fees increased from the pre- to the post-exempt period for non-accelerated filers that had the same auditor throughout the period. This result suggests that the increase in audit fees from the pre- to post-period is not driven by any auditor change effects, or by any unforeseen unique subsample effect, and further supports our hypothesis.

For the second additional analysis, we establish a frame of reference or a benchmark by estimating the regression model using both accelerated and non-accelerated filer companies. The accelerated filers are included in the sample to determine if the reported audit fee increase of non-accelerated filers is the result of a trend in the audit pricing market. To provide a more meaningful comparison between accelerated and non-accelerated filers, we only include accelerated filers with a market capitalization below US\$150m[6]. This allows 


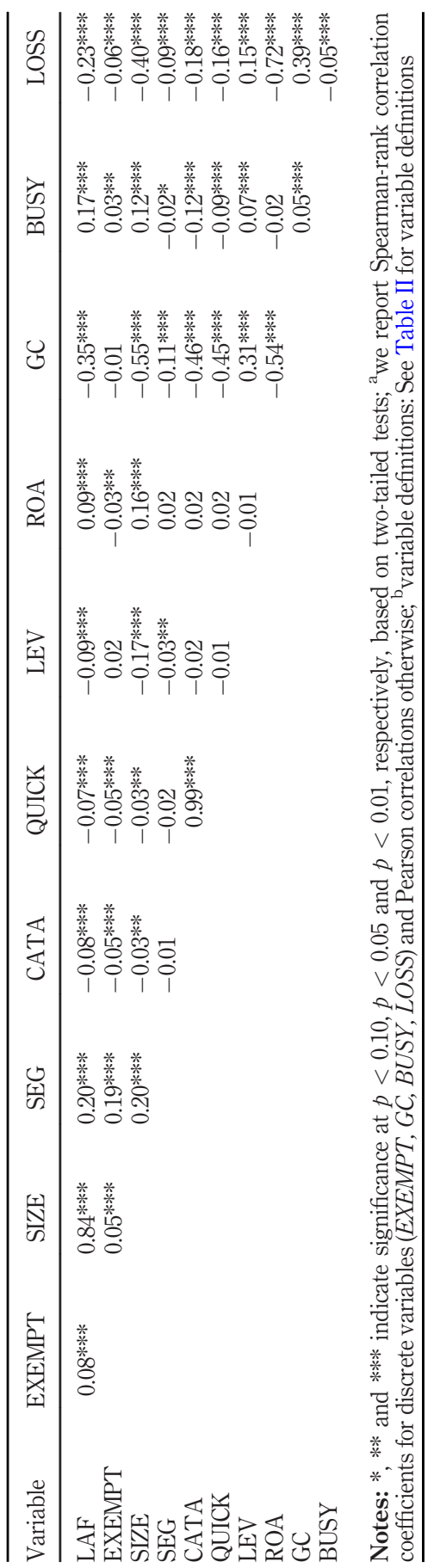

723

Table III. Correlations among variables $^{\mathrm{a}, \mathrm{b}}$ 


$$
\begin{aligned}
L A F= & \alpha+\beta_{1} E X E M P T+\beta_{2} S I Z E+\beta_{3} S E G+\beta_{4} C A T A+\beta_{5} Q U I C K+\beta_{6} L E V \\
& +\beta_{7} R O A+\beta_{8} G C+\beta_{9} B U S Y+\beta_{10} L O S S+\beta_{11-59} I N D
\end{aligned}
$$

\begin{tabular}{|c|c|c|c|c|}
\hline \multirow{2}{*}{724} & Variable $^{\mathrm{a}}$ & Prediction & Estimated coefficients & $t$-statistic \\
\hline & Intercept & None & 10.434 & $133.70^{* * * *}$ \\
\hline & EXEMPT & + & 0.046 & $2.58^{* * * *}$ \\
\hline & SIZE & + & 0.452 & $93.18^{* * * *}$ \\
\hline & SEG & + & 0.038 & $1.84^{* *}$ \\
\hline & CATA & + & 0.046 & $5.43^{* * * *}$ \\
\hline & QUICK & - & 0.043 & $5.00 * * *$ \\
\hline & LEV & + & 0.004 & $8.07 * * *$ \\
\hline & ROA & - & 0.001 & $5.68 * * *$ \\
\hline & $\mathrm{GC}$ & + & 0.177 & 6.52 *** \\
\hline & BUSY & + & 0.072 & $3.66^{* * * *}$ \\
\hline & LOSS & + & 0.264 & $12.86^{* * * * *}$ \\
\hline & Number of observations & 4,984 & & \\
\hline & Adjusted $R^{2}$ & $76.57 \%$ & & \\
\hline & $F$-ratio & $277.07^{* * * *}$ & & \\
\hline
\end{tabular}

Notes: $* *$ and $* * *$ indicate significance at $p<0.05$ and $p<0.01$, respectively (based on one-tailed tests where relation is predicted); andustry dummy variables have been suppressed for expositional convenience; Variable definitions: LAF = natural $\log$ of audit fees in dollars, EXEMPT = 1 if post-SOX 404 (b) exempt period (2010-2012), 0 if pre-SOX 404(b) exempt period (2005-2007), SIZE = the natural log of total assets, $\mathrm{SEG}=$ natural $\log$ of the number of reported business segments, CATA = ratio of current assets to

Table IV.

Audit fee model using full sample total assets, QUICK = ratio of current assets (less inventories) to current liabilities, LEV = ratio of debt to total assets, $\mathrm{ROA}=$ return on assets for the year, $\mathrm{GC}=1$ if audit report is modified for going concern, 0 otherwise, BUSY = 1 if the fiscal year end is December thru March, 0 otherwise, LOSS = 1 if net income is negative, 0 otherwise, IND = dummy variables based on two-digit SIC codes (49 industries)

for a comparison between filer groups using a sample of somewhat similar sized companies. The sample includes 6,113 observations, consisting of 4,984 non-accelerated and 1,129 accelerated filers.

Table VI presents the results of the regression model estimated using both accelerated and non-accelerated filers. The regression model includes a filer status dummy variable, where FILER equals one for non-accelerated filers and 0 for accelerated filers, and an interaction term $(F I L E R \times E X E M P T)$ to tease out the filer status effect on the audit fee and exemption relation. The model is highly significant $(\phi<0.01)$ and the adjusted $R^{2}$ is 76.76 per cent. The results find a significant and positive FILER $\times E X E M P T$ variable, suggesting that the increase in audit fees from the pre- to post-exemption periods for non-accelerated filers is significantly higher than that of accelerated filers. The FILER variable is significant and negative suggesting that nonaccelerated filers have lower audit fees, on average, than those of accelerated filers. The negative coefficient on the EXEMPT variable is not significant in the Table VI results; however, when we expand the accelerated filer sample it does indeed become significant (see endnote 5). These results suggest that the reported increase in audit fees for non-accelerated filers is not simply due to a high-level trend in the audit pricing market.

The third additional analysis teases out the effect of initial audit engagements in the regression model. Specifically, we estimate the OLS regression model using a sample of companies that engaged the same audit firm throughout the study period (same as that used in the first additional analysis). We then included a dichotomous variable (INITIAL) in the 


$$
\begin{aligned}
L A F= & \alpha+\beta_{1} E X E M P T+\beta_{2} S I Z E+\beta_{3} S E G+\beta_{4} C A T A+\beta_{5} Q U I C K+\beta_{6} L E V \\
& +\beta_{7} R O A+\beta_{8} G C+\beta_{9} B U S Y+\beta_{10} L O S S+\beta_{11-59} I N D
\end{aligned}
$$

\begin{tabular}{lccc} 
Variable $^{\mathrm{a}}$ & Prediction & Estimated coefficients & $t$ - statistic \\
\hline Intercept & none & 10.836 & $29.25^{* * *}$ \\
EXEMPT & + & 0.052 & $1.71^{* *}$ \\
SIZE & + & 0.447 & $51.55^{* * *}$ \\
SEG & + & 0.013 & 0.37 \\
CATA & + & 0.028 & 1.13 \\
QUICK & - & 0.004 & 0.16 \\
LEV & + & 0.002 & $3.46^{* * *}$ \\
ROA & - & 0.001 & 0.78 \\
GC & + & 0.156 & $2.41^{* * *}$ \\
BUSY & + & 0.153 & $4.07^{* * *}$ \\
LOSS & + & 0.177 & $4.77^{* * *}$ \\
Number of observations & 1,215 & & \\
Adjusted $R^{2}$ & $86.73^{*} \%$ & & \\
$F-$ Ratio & $199.43^{* * *}$ & &
\end{tabular}

Notes: ** and *** indicate significance at $p<0.05$ and $p<0.01$, respectively (based on one-tailed tests where relation is predicted); ${ }^{a}$ Industry dummy variables have been suppressed for expositional convenience; Variable definitions: LAF = natural log of audit fees in dollars, EXEMPT $=1$ if post-SOX 404(b) exempt period (2010-2012), 0 if pre-SOX 404(b) exempt period (2005-2007), SIZE = the natural log of total assets, SEG = natural $\log$ of the number of reported business segments, CATA = ratio of current assets to total assets, QUICK $=$ ratio of current assets (less inventories) to current liabilities, $\mathrm{LEV}=$ ratio of debt to total assets, $\mathrm{ROA}=$ return on assets for the year, GC = 1 if audit report is modified for going concern, 0 otherwise, BUSY = 1 if the fiscal year end is December thru March, 0 otherwise, LOSS $=1$ if net income is negative, 0 otherwise, IND = dummy variables based on two-digit SIC codes (49 industries)

Table V.

Audit fee model using companies with same auditor for entire sample period

model that equals 1 for companies that had initial audit engagements in the pre-exempt period, and 0 otherwise. In other words, if the company had a new auditor between 2005 and 2007, the INITIAL variable's value for that company equals 1 for all six years in the sample period. Our INITIAL $\times E X E M P T$ interaction term measures the post-exempt audit fees effect for the initial audit engagement observations. The unreported results find a positive and significant INITIAL variable $(\phi<0.01)$, and a negative and non-significant INITIAL $\times$ EXEMPT variable $(\phi=0.47)$. The positive and significant coefficient for the INITIAL variable is consistent with the findings of Huang et al. (2009), who find an initial audit fee premium in 2006. These findings also suggest that the high learning curve of initial audit engagements generally result in higher audit fees.

However, there is no evidence that the initial audit engagements generated significantly greater levels of audit fee discounting from the pre- to post-exempt period as that of existing engagements. Furthermore, the EXEMPT variable remains positive and significant $(p<$ 0.05) suggesting that the reported audit fee discounting result is being driven by existing audit engagements.

The fourth additional analysis considers the potential effect of audit firm size on the audit fee increase from the pre- to post-exemption periods for non-accelerated filers. We estimated the regression including a BIG4 variable and a $B I G 4 \times E X E M P T$ interaction term in the model. The BIG4 is a dummy variable equaling 1 if the auditor is one of the big 4 audit firms, and 0 otherwise. The interaction term $(B I G 4 \times E X E M P T)$ teases out the BIG4 


$$
\begin{aligned}
L A F= & \alpha+\beta_{1} E X E M P T+\beta_{2} \text { FILER }+\beta_{3}(\text { FILER } \times \text { EXEMPT })+\beta_{4} \text { SIZE } \\
& +\beta_{5} S E G+\beta_{6} C A T A+\beta_{7} Q U I C K+\beta_{8} L E V+\beta_{9} R O A+\beta_{10} G C \\
& +\beta_{11} B U S Y+\beta_{12} L O S S+\beta_{13-61} I N D
\end{aligned}
$$

\begin{tabular}{lccr} 
Variable $^{\mathrm{a}}$ & Prediction & Estimated coefficients & $t$-statistic \\
\hline Intercept & none & 10.674 & $149.78^{* * * *}$ \\
EXEMPT & none & 0.033 & 0.89 \\
FILER & - & 0.351 & $11.38^{* * * *}$ \\
FILER $\times$ EXEMPT & + & 0.072 & $1.76^{* *}$ \\
SIZE & + & 0.462 & $102.33^{* * *}$ \\
SEG & + & 0.062 & $3.50^{* * *}$ \\
CATA & + & 0.042 & $5.14^{* * *}$ \\
QUICK & - & 0.038 & $4.64^{* * *}$ \\
LEV & + & 0.004 & $8.46^{* * *}$ \\
ROA & - & 0.001 & $5.96^{* * *}$ \\
GC & + & 0.206 & $8.07^{* * *}$ \\
BUSY & + & 0.065 & $3.68^{* * *}$ \\
LOSS & + & 0.270 & $14.85^{* * *}$ \\
Number of observations & 6,113 & & \\
Adjusted $R^{2}$ & & & \\
$F$-Ratio & $76.76^{*} \%$ & &
\end{tabular}

Table VI.

Audit fee model using both accelerated and nonaccelerated filers
Notes: $* *$ and $* * *$ indicate significance at $p<0.05$ and $p<0.01$, respectively (based on one-tailed tests where relation is predicted); ${ }^{a}$ Industry dummy variables have been suppressed for expositional convenience; Variable definitions: LAF = natural log of audit fees in dollars, EXEMPT $=1$ if post-SOX 404(b) exempt period (2010-2012), 0 if pre-SOX 404(b) exempt period (2005-2007), FILER = 1 if non-accelerated filer (market capitalization below US\$75m), 0 if accelerated filer with market capitalization between US\$75m and US\$150m, $\mathrm{SIZE}=$ the natural $\log$ of total assets, $\mathrm{SEG}=$ natural $\log$ of the number of reported business segments, $\mathrm{CATA}=$ ratio of current assets to total assets, QUICK = ratio of current assets (less inventories) to current liabilities, $\mathrm{LEV}=$ ratio of debt to total assets, $\mathrm{ROA}=$ return on assets for the year, $\mathrm{GC}=1$ if audit report is modified for going concern, 0 otherwise, BUSY = 1 if the fiscal year end is December thru March, 0 otherwise, LOSS = 1 if net income is negative, 0 otherwise, IND = dummy variables based on two-digit SIC codes (49 industries)

effect on the audit fee increase from the pre- to post-exemption periods. The unreported results find both the $B I G 4$ and $B I G 4 \times E X E M P T$ variables positive and significant. This suggests that non-accelerated filers with BIG4 auditors experienced a significant increase in audit fees from the pre- to post-exemption period above and beyond that of non-accelerated filers with non-BIG4 auditors. The EXEMPT variable remains positive and marginally significant $(p=0.07)$. This result suggests that nonaccelerated filers with non-BIG4 auditors experienced an increase in audit fees from the pre- to post-exemption periods.

The fifth and final additional analysis considers a more complete landscape of audit fees post-SOX by analyzing audit fees for an extended sample period prior to our pre-exemption period (i.e. 2002-2004). We estimated our regression model using 2002-2004 and 2002-2007 as the pre-exemption periods. The untabulated results from these models remain qualitatively consistent with our main results presented in Table IV.

We find that, on average, audit fees increased 59 per cent from 2002-2004 to 2005-2007 and increased 25 per cent from 2005-2007 to 2010-2012. The significant increase in fees from the 2002-2004 to the 2005-2007 is not overly surprising given the tumultuous public company auditing environment in the years immediately following SOX for both 
accelerated and nonaccelerated filers. Bedard et al. (2008) identify a "spillover" effect that caused audit fees for non-accelerated filers to increase drastically from 2003 to 2004, even though these companies did not encounter a change in auditing regulation (i.e. SOX 404) during this time.

The authors identify several possible reasons as to why audit fees went up for nonaccelerated filers during this period. First, auditors may be demanding a higher level of assurance for all financial statement audits due to the increased scrutiny on public companies' financial statements post-SOX. Second, audit firms were forced to change their auditing methodology to comply with the integrated audit requirement of SOX; this change in methodology likely affected non-accelerated clients as well. This "learning curve" effect would likely increase audit fees. Third, the demise of Arthur Andersen decreased competition in the audit market, which in turn increased audit fees. Finally, the accounting scandals that led to this demise and to the implementation of SOX likely caused auditors to increase their fees to decrease their litigation exposure (Bedard et al., 2008). We conclude that these conditions were unique to the period immediately following SOX, and we do not foresee their effects lingering during our study's pre- and post-exemption periods.

In sum, the results of the additional analyses suggest that the reported increase in audit fees from the pre- to post-exemption periods for non-accelerated filers is robust.

\section{Conclusion}

In this study, we examine the following research question: did auditors engage in the practice of audit fee discounting for their non-accelerated filer clients in anticipation of those companies' upcoming compliance with the SOX 404(b) integrated audit requirement? Prior research provides mixed results related to audit fee discounting, specifically during the postSOX era. We theorize that auditors would be motivated to discount fees for their nonaccelerated clients for the years 2005-2007; during this period, SOX 404(b) implementation was expected to occur imminently for non-accelerated filers. Thus, motivated by the prospect of future economic rents (DeAngelo, 1981), auditors discounted their audit fees for those clients.

We operationalize this research question by comparing audit fees paid by nonaccelerated filers during the pre-SOX 404(b) permanent exemption period (2005-2007) and the post-SOX 404(b) permanent exemption period (2010-2012). We hypothesize that nonaccelerated filer audit fees are lower during the pre-exemption period compared with the post-exemption period (H1), supporting the notion of audit fee discounting.

Using an Audit Analytics sample of non-accelerated filers, our results provide evidence that audit fees increased significantly for non-accelerated filers post-exemption. This evidence provides support for $H 1$. These results are quite intuitive: auditors raised their audit fees post-exemption due to a change in expected future economic rents.

This study provides an incremental contribution to this literature stream by first identifying audit fee discounting in a unique setting, allowing us to make conclusions about the occurrence of audit fee discounting as a whole rather than through the narrower lens of initial audit fee discounting studied in prior literature. Additionally, we find specific support for audit fee discounting in continuing audit engagements, while initial audit fees are higher in our pre-exemption period, consistent with Huang et al. (2009). We also identify a potential unintended consequence of the integrated audit requirement: impaired independence and decreased audit quality for non-accelerated filers and a subsequent increase in audit costs to those firms after the exemption occurred. This finding should be useful to investors, regulators and practitioners, as they continue to consider the practice of audit fee discounting in the post-SOX environment. 
A limitation of this study is the assumption that auditors did not anticipate the permanent SOX 404(b) exemption for non-accelerated filers. To address this limitation, we did an exhaustive search of the business press related to the topic of a permanent exemption for these companies and found no mention of even the possibility of a permanent exemption until October 2009. Thus, we are comfortable with this assumption but acknowledge that we are unable to verify the prevailing expectation of auditors during this period.

\section{Notes}

1. See the details of these delays in the sample section of our paper.

2. We completed a comprehensive search of 2009 business press articles using Google and LexisNexis Academic, searching for key related terms such as "SOX 404(b)", "permanent exemption", "non-accelerated filers", etc. There was no mention of the possibility of a permanent SOX 404(b) exemption for non-accelerated filers until Congressman Garrett's legislation was introduced to Congress in October 2009.

3. Non-accelerated filers are companies with public float less than US\$75m. For observations with missing price or common share data per Research Insight, we determined their filer status per Audit Analytics.

4. Granted, there are alternative explanations for this univariate increase in audit fees from the preto post-exemption period. For example, as many companies struggled through the 2008 financial crisis and recession, there was an increase in going concern opinions issued (Table II). This increased the audit effort needed to audit those clients, as well as the risk undertaken by auditors to audit those clients. An increase in effort and risk would increase audit fees.

5. Following Halverson and Palmquist (1980), the interpretation of a dummy variable coefficient regressed on a natural log dependent variable is determined by subtracting 1 from the antilog of the coefficient (as referenced in Gujariti, 1995, p. 526).

6. The results remain qualitatively similar as to those reported in Table VI when we use a size cutoff of US $\$ 300 \mathrm{~m}$ for accelerated filers, and when we include all accelerated filers. The exception is the variable EXEMPT becomes significant (negative) in these models.

\section{References}

Aguilar, M. (2009a), “404(b) for Small Cos. Delayed to FYEs Until June 15, 2010”, available at: www. complianceweek.com/404b-for-small-cos-delayed-to-fyes-until-june-152010/article/187264 (accessed 27 May 2014).

Aguilar, M. (2009b), "Financial Regulation Moves Ahead, With SOX Exemption", available at: www. complianceweek.com/financial-regulation-moves-ahead-with-soxexemption/article/187303/_ (accessed 27 May 2014).

American Institute of Certified Public Accountants (AICPA) (1978), Commission on Auditors' Responsibilities: Report, Conclusions, and Recommendations, AICPA, New York, NY.

Bedard, J., Hoitash, U. and Hoitash, R. (2008), "Audit pricing and internal control disclosures among non-accelerated filers”, Research in Accounting Regulation, Vol. 20, pp. 103-126.

Craswell, A., Francis, J. and Taylor, S. (1995), "Auditor brand name reputations and industry specializations”, Journal of Accounting \& Economics, Vol. 20 No. 3, pp. 297-322.

Craswell, A. and Francis, J. (1999), "Pricing initial audit engagements: a test of competing theories", The Accounting Review, Vol. 74 No. 2, pp. 201-216.

DeAngelo, L.E. (1981), “Audit independence, 'low balling', and disclosure regulation”, Lournal of Accounting and Economics, Vol. 3 No. 2, pp. 113-127. 
Desir, R., Casterella, J. and Kokina, J. (2014), “A reexamination of audit fees for initial audit engagements in the post-SOX period", Auditing: A Journal of Practice and Theorv, Vol. 33 No. 2, pp. 59-78.

Ettredge, M. and Greenberg, R. (1990), "Determinants of fee cutting on initial audit engagements", Journal of Accounting Research, Vol. 28 No. 1, pp. 198-210.

Ettredge, M., Fuerherm, E. and Li, C. (2014), "Fee pressure and audit quality", Accounting. Organizations, and Society, Vol. 39 No. 4, pp. 247-263.

Ferguson, A., Francis, J. and Stokes, D. (2003), "The effects of firm-wide and office-level industry expertise on audit pricing", The Accounting Review, Vol. 78 No. 2, pp. 429-448.

Francis, J., Reichelt, K. and Wang, D. (2005), "The pricing of national and city-specific reputations for industry expertise in the US audit market", The Accounting Review, Vol. 80 No. 1, pp. 133-136.

Frankel, R., Johnson, M. and Nelson, K. (2002), "The relation between auditors' fees for nonaudit services and earnings management", The Accounting Review, Vol. 77 No. s1, pp. 71-105.

Ghosh, A. and Lustgarten, S. (2006), "Pricing of initial audit engagements by large and small audit firms", Contemporary Accounting Research, Vol. 23 No. 2, pp. 333-368.

Ghosh, A. and Pawlewicz, R. (2009), "The impact of regulation on auditor fees: evidence from the sarbanes-oxley act", Auditing: A Journal of Practice and Theory, Vol. 28 No. 2, pp. 171-197.

Gujariti, D.N. (1995), Basic Econometrics, 3rd edn., McGraw-Hill, New York, NY.

H.R. 3775. (2009), "111th congress: small business SOX compliance relief act", available at: www. govtrack.us/congress/bills/111/hr3775 (accessed 15 August 2014).

H.R. 4173. (2010), "111th congress: Dodd-frank wall street reform and consumer protection act", available at: www.govtrack.us/congress/bills/111/hr4173 (accessed 21 August 2014).

Halverson, R. and Palmquist, R. (1980), "The interpretation of dummy variables in semilogarithmic equations”, American Economic Review, Vol. 70 No. 3, pp. 474-475.

Hansen, G. (2010), "Audit fees and engagement profitability: a threats and safeguards approach to strengthen compliance with standards of ethical behaviour", available at: http://nasba.org/files/ 2011/03/Ethics_and_Strategic_Issues_Discussion-22Oct20.pdf (accessed 18 January 2016).

Huang, H., Raghunandan, K. and Rama, D. (2009), “Audit fees for initial audit engagements before and after SOX”, Auditing: A Iournal of Practice and Theory, Vol. 28 No. 1, pp. 171-190.

Kanodia, C. and Mukherji, A. (1994), "Audit pricing, lowballing and auditor turnover: a dynamic analysis", The Accounting Review, Vol. 69 No. 4, pp. 593-615.

Krishnan, J., Rama, D. and Zhang, Y. (2008), "Costs to comply with SOX section 404", Auditing: A Lournal of Practice and Theory, Vol. 27 No. 1, pp. 169-186.

Krishnan, G. and Zhang, Y. (2014), "Is there a relation between audit fee cuts during the global financial crisis and banks' financial reporting quality?", Journal of Accounting and Public Policy, Vol. 33 No. 3, pp. 279-300.

Nagy, A.L. (2014), “Audit partner specialization and audit fees”, Managerial Auditing Journal, Vol. 29 No. 6, pp. 513-526.

Public Company Accounting Oversight Board (PCAOB) (2004), Auditing Standard No. 2: An Audit of Internal Control Over Financial Reporting Performed in Conjunction With and Audit of Financial Statements, PCAOB, Washington, DC, available at: https://pcaobus.org//Standards/Auditing/ Pages/Auditing_Standard_2.aspx (accessed 6 June 2017).

Public Company Accounting Oversight Board (PCAOB) (2011), "Concept Release on Auditor Independence and Audit Firm Rotation”, Rulemaking Docket Matter No. 37: Release No. 2011006, available at: http://pcaobus.org/rules/rulemaking/docket037/release_2011-006.pdf (accessed 18 January 2016).

Raghunandan, K. and Rama, D.V. (2006), "SOX section 404 material weakness disclosures and audit fees", Auditing: A Journal of Practice \& Theory, Vol. 25 No. 1, pp. 99-114. 
Sankaraguruswamy, S. and Whisenant, S. (2009), "Pricing Initial Audit Engagements: Empirical Evidence Following Public Disclosure of of Audit Fees", Working paper, National University of Singapore and University of Kansas, available at: http://papers.ssrn.com/sol3/papers.cfm? abstract_id $=452680$

Sankaraguruswamy, S., Whisenant, S. and Willenborg, M. (2012), "Pricing and quality of initial audit engagements", Working paper, National University of Singapore, University of Houston, and University of Connecticut.

Simon, D.T. and Francis, J.R. (1988), "The effect of auditor change on audit fees: Tests of price cutting and price recovery", The Accounting Review, Vol. 63 No. 2, pp. 255-269.

Simunic, D. (1980), "The pricing of audit services: Theory and evidence", Lournal of Accounting Research, Vol. 18 No. 1, pp. 161-190.

Stanley, J. and DeZoort, F. (2007), "Audit firm tenure and financial restatements: an analysis of industry specialization and fee effects", Journal of Accounting and Public Policy, Vol. 26 No. 2, pp. 131-159.

Walker, P. and Casterella, J. (2000), "The role of auditee profitability in pricing new audit engagements", Auditing: A Journal of Practice and Theory, Vol. 19 No. 1, pp. 157-167.

\section{Corresponding author}

Benjamin W. Hoffman can be contacted at: bhoffm11@kent.edu 